\title{
THE ROLE OF TRUST IN MEDIATING THE EFFECT OF EWOM AND SHOPPING EXPERIENCE ON CUSTOMER LOYALTY
}

\author{
Wibawa I Gede Andika Satria*, Setiawan Putu Yudi \\ Faculty of Economics and Business, University of Udayana, Indonesia \\ ${ }^{*}$ E-mail: andikasatriaa28@gmail.com
}

\begin{abstract}
Customer loyalty is important in marketing because it represents the desire of customers, employees or friends to make personal investments or sacrifices to strengthen the relationship between them. The purpose of this study is to determine the role of trust in mediating the effect of eWOM and shopping experience on customer loyalty to Tokopedia application users in Denpasar. The subjects of this research are Tokopedia users, the questionnaires were distributed to 105 respondents through online media by first compiled in a Google-form link format. Determination of the sample using a non-probability sampling method, namely purposive sampling. The data were analyzed using the SEM-PLS technique. The results of this study show that eWOM has a positive and significant effect on customer loyalty, eWOM has a positive and significant effect on trust, shopping experience has a positive and significant effect on customer loyalty, shopping experience has a positive and significant effect on trust, trust has a positive and significant effect on customer loyalty, trust able to mediate the effect of eWOM on customer loyalty, and trust is able to mediate the effect of shopping experience on customer loyalty. The practical implication that can be given from the research findings is that this study can be used as a basic model to evaluate Tokopedia's strategy for eWOM, shopping experience, trust, and customer loyalty. Based on the results of statistical data, that among the three variables that affect customer loyalty, the eWOM variable has the highest path coefficient, which can be a reference for Tokopedia management in making strategies to increase customer loyalty.
\end{abstract}

\section{KEY WORDS}

eWOM, shopping experience, trust, customer loyalty, Tokopedia.

Digital developments have changed consumer behavior in shopping activities. According to a survey from United Parcel Service (UPS), a document and package delivery company from the United States (US), it was found that consumers make most of their purchases online (UPS, 2016). Consumers are increasingly using the advantages of the online environment to find information about products and services that are integrated into their purchasing decision processes (Teng et al., 2014). Recent research has shown that the internet allows customers to use online platforms to share reviews with other users (Kim and Park, 2013). This digital development makes the internet not only used as a medium for finding information or socializing media, but is now also used as a means of shopping.

Based on the results of the Indonesian internet user penetration survey 2019-2020 (Q2), Indonesia's total internet users currently reach 196.7 million users with a penetration of 73.3 percent of Indonesia's total population of around 266.9 million. In addition, in the Bali area itself, about 59 percent of the population is connected to the internet. The number of internet users increased significantly compared to the results of the 2018 survey which reached 171.1 million internet users with a penetration of 64.8 percent. The use of the internet in Indonesia is the highest online buying and selling actor in the world. According to We Are Social data, the country with the largest e-commerce adoption (use) in the world. The figure reaches 88 percent of all internet users in Indonesia. The use of e-commerce in Indonesia itself is used to find information about a product via the internet and then make transactions online.

According to Schiffman and Kanuk (2011: 265) when the number of internet users increases geometrically and more and more people use websites to search for product 
information, that is the peak of online shop usage. One of the largest mobile e-commerce from Indonesia is Tokopedia. Tokopedia is an Indonesian technology company with a mission to achieve economic equality digitally. Tokopedia has transformed into a unicorn that is influential not only in Indonesia but also in Southeast Asia. Tokopedia has the leading marketplace business in Indonesia that allows individuals, small shops, and brands to open and manage online stores.

In 2018, Tokopedia again won several awards. Last May, the Tokopedia application managed to top the Apple Store beating Facebook, WhatsApp, and Instagram. While on Android, Tokopedia also managed to become the \#3 Top Chart on Google Play beating Facebook and Instagram. In December 2018 Tokopedia was chosen as the best application of choice for the community on Google Play.

Regarding the achievements of Tokopedia's e-commerce, there are 15 million Tokopedia user data allegedly leaked in cyberspace. In fact, the latest news mentions that the data of 91 million users and more than seven million Tokopedia merchants are sold on dark web sites. The data is sold at a price of 5,000 US dollars (about Rp. 74 million). This incident will certainly harm the affected users. The victim's e-mail has the potential to be misused for criminal acts, such as fraud or extortion. Tokopedia admitted that there was an attempt to steal user data on its e-commerce platform. This of course will affect consumer confidence from Tokopedia itself. The survey was conducted to see the impact of the data leak on 20 Tokopedia users. Based on data obtained from 8 respondents or $40 \%$ stated that information leakage is negative news that makes consumers feel worried.

Perceptions, either positive or negative, influence customers' trust in e-commerce and trust in sellers which in turn, shape customer repurchase intentions as a form of loyalty (Liu and Tang, 2018). Customer loyalty describes the consumer's desire to repurchase from a company in the long term and recommend the company's products or services to others in a business context (Wirtz, Chew \& Lovelock, 2012; Saeed et al., 2013). A number of challenges arise in attracting potential customers. After a customer visits a particular emarketplace, the challenge for e-retailers is how to persuade that customer to repurchase from the same platform (Trivedi and Yadav, 2017). It costs less to retain an existing customer than it does to acquire a new customer. These repeat customers spend more money on their purchases and make more profit than new customers (Patel, 2014).

After the initial purchase, customers gain hands-on experience with these mechanisms and form their own perceptions of the benefits of online trust-building mechanisms (Liu and Tang, 2018). Customer loyalty is important in marketing because it represents the desire of customers, employees or friends to make personal investments or sacrifices to strengthen the relationship between them (Shpëtim, 2012). Therefore, the perceived usefulness of this mechanism should play an important role in influencing customer repurchase intention. Positive or negative perceptions can be obtained through the customer's shopping experience (shopping experience) or through reviews obtained through websites and online e-commerce media (electronic word of mouth).

The shopping experience is a factor in trust that compares reputation and reality so that the expectations of the product or service are as expected (Ardyanto, 2013). They propose that the customer experience is cognitive, social, affective, and physical. Customer experience is not only connected to hedonic consumption, but is also part of utilitarian values (Tingting, 2018). Consumer experience in online media becomes very important in adapting new technology because vendors serve buyers in unexpected ways. Consumers who make purchases online will depend on the quality of the experience where experience can be obtained only through previous purchase experiences (Parastanti, 2014).

According to Jacobsen (2018) eWOM is a positive or negative statement made by potential, actual, or existing customers about a product or company, which is available to many people and institutions through the Internet. eWOM is available through new communication opportunities including blogs, social networking sites (Twitter, Facebook, and others). This increased participation in eWOM has led to various studies on impact and diffusion (King et al, 2014). Online review is a form of eWOM that is getting increasing attention in the literature (Trenz and Berger, 2013). 
Shopping experience and eWOM in influencing customer loyalty are shaped by customer trust. Trust is the consumer's belief in the seller's good intentions, integrity, and competence in a situation, the consumer's willingness to accept any risk, and the consumer's willingness to provide information about himself when making transactions through the internet (Aangkat and Prihatini, 2018). Consumers who have trust after using an online service will spread positive values, so trust has a positive and significant influence on WOM (Putra et al. 2016). Research on the electronic word of mouth variable has a positive and significant effect on customer loyalty (Purwanda and Wati, 2018) and shopping experience has a positive effect on customer loyalty (Pujiawati, 2020). However, this is not supported by Park's research (2020) that eWOM information has no effect on customer loyalty because consumers filter information from a collection before using it. The above studies have revealed the impact of eWOM on social media, but the relationship between eWOM information and customer loyalty has not been explored. According to Zhong and Moon (2020) found that a pleasant shopping experience has no effect on satisfaction and loyalty because it is a post-consumption effect, while happiness is before consumption. Based on the background and previous research, the conceptual framework and hypotheses in this study are as follows:

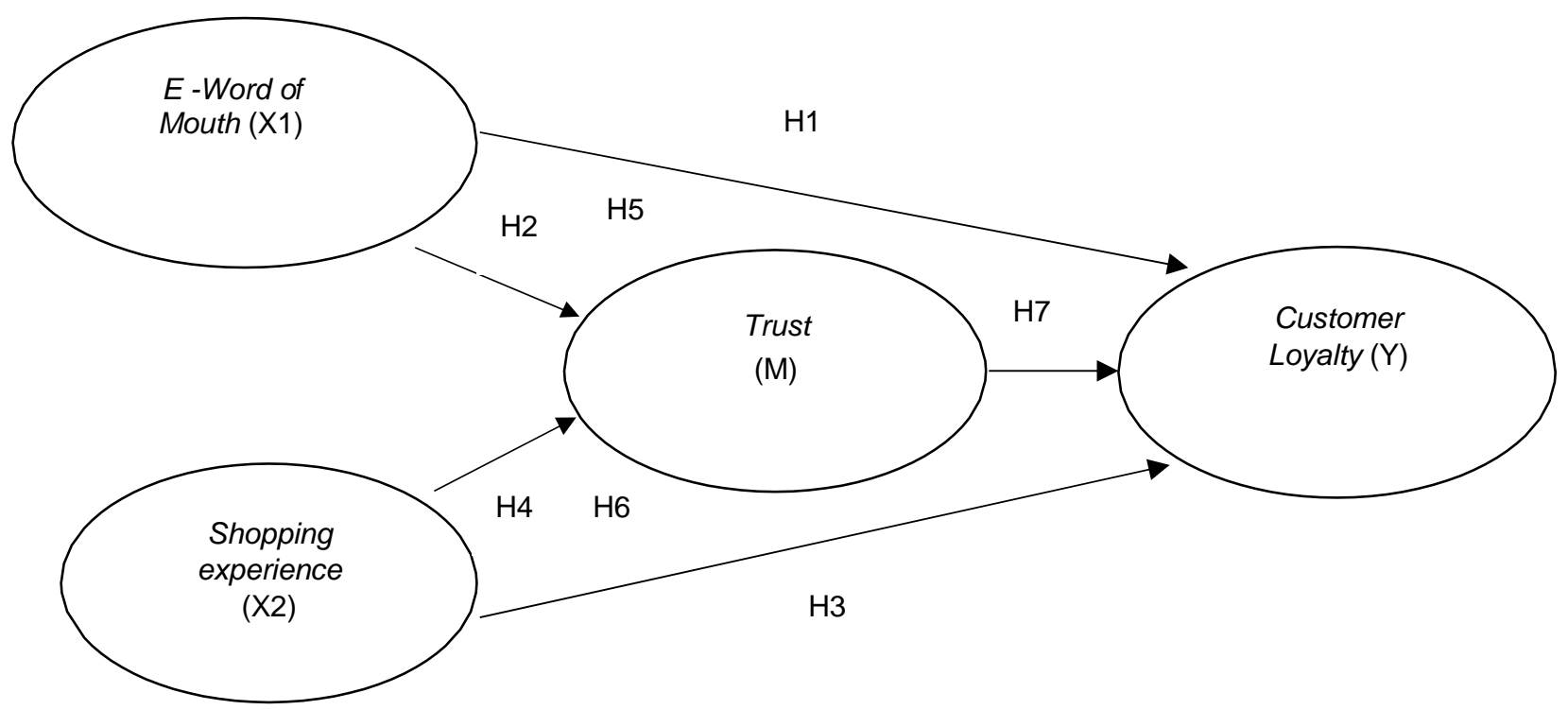

Figure 1 - Conceptual Framework. Source: Prastyaningsih (2014), Anggitasari and Wijaya (2016), Atika, dkk. (2017), Wilson and Keni (2018), Serra, et al (2019), Bu, et al (2020)

H1: eWOM has a positive and significant effect on customer loyalty;

$\mathrm{H}$ 2: eWOM has a positive and significant effect on trust;

H3: Shopping experience has a positive and significant effect on customer loyalty;

$\mathrm{H} 4$ : Shopping experience has a positive and significant effect on trust;

H5: Trust has a positive and significant effect on customer loyalty;

H6: Trust is able to mediate the effect of eWOM on customer loyalty;

$\mathrm{H} 7$ : Trust is able to mediate the effect of shopping experience on customer loyalty.

\section{METHODS OF RESEARCH}

This research uses quantitative data which is analyzed associatively. The population in this study is all users of the Tokopedia application who are domiciled in Denpasar City with an infinite number of unknowns. The non-probability sampling technique used in this study is purposive sampling, ie the sample is determined in a certain number of certain criteria. The best recommended sample size for measuring multivariate is $5-10$ observations per estimated parameter. Thus, the respondents needed in this study are $21 \times 5=105$ 
respondents. The data analysis technique in this study is descriptive and inferential using SEM PLS.

Table 1 - Research Construct

\begin{tabular}{|c|c|c|c|}
\hline Variable & Dimension & Indicator & References \\
\hline \multirow[t]{3}{*}{$E W O M(\mathrm{X} 1)$} & Intensity & $\begin{array}{l}\text { - Frequency in accessing information } \\
\text { - Frequency of interaction with other } \\
\text { consumers } \\
\text { - The number of opinions from } \\
\text { consumers }\end{array}$ & \multirow[t]{3}{*}{ Goyette et al.,(2010), Adeliasari, et al. (2012) } \\
\hline & $\begin{array}{l}\text { Valence of } \\
\text { opinion }\end{array}$ & $\begin{array}{l}\text { - Positive comments from users } \\
\text { - Recommendations from other users } \\
\text { - Experience and evidence supporting } \\
\text { users' positive arguments }\end{array}$ & \\
\hline & Content & $\begin{array}{l}\text { - Product variety information } \\
\text { - Product quality information } \\
\text { - Information about the price offered }\end{array}$ & \\
\hline \multirow[t]{4}{*}{$\begin{array}{l}\text { Shopping } \\
\text { Experience (X2) }\end{array}$} & & $\begin{array}{l}\text { Consumer experience in obtaining } \\
\text { various information about the product }\end{array}$ & \multirow{4}{*}{$\begin{array}{l}\text { Giantari et al. (2013), Parastanti dkk. (2014), } \\
\text { Megantara and Suryani (2016), and Astarina et } \\
\text { al. (2017) }\end{array}$} \\
\hline & & $\begin{array}{l}\text { The feeling of pleasure that consumers } \\
\text { have when shopping online }\end{array}$ & \\
\hline & & $\begin{array}{l}\text { the convenience felt by consumers in } \\
\text { shopping online }\end{array}$ & \\
\hline & & $\begin{array}{l}\text { Convenience felt by consumers when } \\
\text { shopping online }\end{array}$ & \\
\hline \multirow[t]{5}{*}{ Trust $\left(\mathrm{Y}_{1}\right)$} & & Consumer trust in a good reputation & \multirow{5}{*}{$\begin{array}{l}\text { Karjaluoto et al. (2016) and Astarina et al. } \\
(2017)\end{array}$} \\
\hline & & $\begin{array}{l}\text { Consumer confidence in system } \\
\text { reliability }\end{array}$ & \\
\hline & & $\begin{array}{l}\text { Consumer confidence in safety in online } \\
\text { shopping }\end{array}$ & \\
\hline & & $\begin{array}{l}\text { Consumer trust that Tokopedia } \\
\text { provides honest information. }\end{array}$ & \\
\hline & & Overall consumer confidence & \\
\hline \multirow{3}{*}{$\begin{array}{l}\text { Customer } \\
\text { Loyalty }\left(\mathrm{Y}_{2}\right)\end{array}$} & & Say positive thing & \multirow[t]{3}{*}{ Zeithaml, et al. (2009: 47) } \\
\hline & & Recommend friends & \\
\hline & & Continue purchasing & \\
\hline
\end{tabular}

\section{RESULTS AND DISCUSSION}

Research data obtained from questionnaires that have been distributed to all respondents, amounting to 105 people. Based on the data obtained through the questionnaire, the characteristics of the respondents, as presented in Table 5.1, the number of respondents who are female is more with a percentage value of $51.4 \%$ and male respondents are $48.6 \%$. Respondents aged $21-25$ years more with a percentage of $80 \%$. Respondents with the most private employee jobs with a percentage of $49.5 \%$. Characteristics of respondents can be used as information about the mapping of respondents from the characteristics of gender, age, education, and occupation. The results in Table 5.1 show that there are more female respondents than male respondents, aged between 21-25, and the highest occupation is private employees.

There are five direct influence hypotheses that were tested using Partial Least Square (PLS). This test is carried out using the t-test (t-test) on each path of influence between variables. In PLS statistical testing of each hypothesized relationship is carried out using the bootstrap method on the sample. Testing with bootstrap is also intended to minimize the problem of abnormal research data. The results of the direct influence test on the structural equation analysis are presented in Table 2.

Table 2 - Direct Effect Test Results

\begin{tabular}{|c|c|c|c|c|}
\hline & Original Sample $(\mathrm{O})$ & T Statistics (|O/STDEV|) & $P$ Values & Information \\
\hline EWOM -> Customer Loyalty & 0,303 & 2,278 & 0,012 & Significant \\
\hline EWOM -> Trust & 0,525 & 5,485 & 0,000 & Significant \\
\hline Shopping Experience -> Customer Loyalty & 0,293 & 3,838 & 0,000 & Significant \\
\hline Shopping Experience -> Trust & 0,335 & 3,308 & 0,001 & Significant \\
\hline Trust -> Customer Loyalty & 0,346 & 2,773 & 0,003 & Significant \\
\hline
\end{tabular}

Source: Primary Data, processed (2021). 
Examination of the mediation variable in this study will examine the mediating role of the trust variable on the indirect effect of eWOM and shopping experience on customer loyalty. The examination of the indirect effect in this study can be seen in the explanation of the results of the analysis in Table 3 as follows.

Table 3 - Direct Effects, Indirect Effects, Total Variable Effects, and VAF Calculations

\begin{tabular}{|c|c|c|}
\hline \multirow[t]{2}{*}{ Variable } & \multicolumn{2}{|l|}{ Direct effect } \\
\hline & Coef. Correlation & t-Statistics \\
\hline EWOM -> Customer Loyalty & 0,303 & 2,278 \\
\hline EWOM -> Trust & 0,525 & 5,485 \\
\hline Shopping Experience -> Customer Loyalty & 0,293 & 3,838 \\
\hline Shopping Experience -> Trust & 0,335 & 3,308 \\
\hline Trust -> Customer Loyalty & 0,346 & 2,773 \\
\hline \multirow[t]{2}{*}{ Variable } & \multicolumn{2}{|l|}{ Indirect Effect } \\
\hline & Coef. Correlation & t-Statistics \\
\hline EWOM -> Trust -> Customer Loyalty & 0,182 & 2,347 \\
\hline Shopping Experience -> Trust -> Customer Loyalty & 0,116 & 2,055 \\
\hline \multirow[t]{2}{*}{ Variable } & \multicolumn{2}{|l|}{ Total Effect } \\
\hline & Coef. Correlation & t-Statistics \\
\hline EWOM -> Customer Loyalty & 0,485 & 5,285 \\
\hline EWOM -> Trust & 0,525 & 5,485 \\
\hline Shopping Experience -> Customer Loyalty & 0,409 & 4,738 \\
\hline Shopping Experience -> Trust & 0,335 & 3,308 \\
\hline Trust $->$ Customer Loyalty & 0,346 & 2,773 \\
\hline VAF -> Indirect effect / Total effect $(0.182 / 0.485)$ & 0.375 & \\
\hline VAF -> Indirect effect / Total Effect $(0,116 / 0,525)$ & 0.221 & \\
\hline
\end{tabular}

The criteria for assessing the mediating effect can be based on the VAF value. If the value of VAF $>80 \%$ then the mediation variable is full mediation, if $20 \%$ VAF $80 \%$ then the mediation variable is partial mediation and if $<20 \%$ then the mediation variable is not a mediator.

Table 4 - Recapitulation of Mediation Variable Test Results

\begin{tabular}{llllll}
\hline Path Relationship & Effect & \multicolumn{3}{c}{ Information } \\
\cline { 2 - 5 } & $(\mathrm{A})$ & (B) & (C) & (D) & \\
\hline eWOM (X1) -> Trust (Y1) -> Customer Loyalty (Y2) & 0,182 & 0,303 & 0,525 & 0,346 & Partial \\
& (Sig.) & (Sig.) & (Sig.) & (Sig.) & Mediation \\
Shopping Experience (X2) -> Trust (Y1) -> Customer & 0,116 & 0,293 & 0,335 & 0,346 & Partial \\
Loyalty (Y2) & (Sig.) & (Sig.) & (Sig.) & (Sig.) & Mediation \\
\hline
\end{tabular}

Source: Data Processing Results, 2021.

Description: significance (Sig.) = t-statistic $>1,96$ on $a=5 \%$.

(A): indirect effect of exogenous variables (X1 or $X 2)$ on endogenous variables (Y1).

(B): direct effect of exogenous variables ( $X 1$ or $X 2)$ on endogenous variables (Y2).

(C): direct effect of exogenous variables ( $X 1$ or $X 2)$ on endogenous variables (Y1).

(D): direct effect of endogenous variable (Y1) on endogenous variable (Y2).

The effect of eWOM on customer loyalty. Based on the data presented in Table 2, it is known that eWOM has a positive and significant effect on customer loyalty to Tokopedia users in Denpasar. This result means that the better eWOM, the higher the customer loyalty for Tokopedia users in Denpasar City.

These results indicate that the values contained in eWOM have a significant impact on Tokopedia's customer loyalty. The eWOM variable measured is based on: the frequency of consumers accessing information on social networking sites, the frequency of interactions with other consumers on social networking sites, the number of opinions from consumers who have made purchases, positive comments from users of social networking sites, recommendations from users of social networking sites, experience and evidence supporting positive arguments for the use of products from users of social networking sites, information on product variations, product quality information, information on prices offered that are considered important have proven to be able to influence customer loyalty to Tokopedia. So that it can be interpreted that it will be able to make a significant contribution in increasing customer loyalty to Tokopedia users. 
The results of this study are in accordance with the results of previous studies, namely there is a positive relationship between eWOM and customer loyalty (Serra et al, 2018) on the other hand, it is recognized that positive comments have a positive impact on brand reputation thereby helping companies to attract new customers and increase the tendency of these new customers. to be loyal (Yacouel and Fleischer, 2012). eWOM has a positive and significant effect on customer loyalty (Purwanda and Wati, 2018). eWOM has a significant effect on customer loyalty (Kadek et al, 2015).

Effect of eWOM on trust. Based on the data presented in Table 2, it is known that eWOM has a positive and significant effect on trust in Tokopedia users in Denpasar. This result means that the better eWOM, the higher the trust for Tokopedia users in Denpasar City.

These results indicate that the values contained in eWOM have a significant impact on Tokopedia's trust. The eWOM variable measured is based on: the frequency of consumers accessing information on social networking sites, the frequency of interactions with other consumers on social networking sites, the number of opinions from consumers who have made purchases, positive comments from users of social networking sites, recommendations from users of social networking sites, experience and evidence supporting positive arguments for the use of products from users of social networking sites, information on product variations, information on product quality, information on prices offered that are considered important are proven to be able to influence trust in Tokopedia. So that it can be interpreted that this will be able to make a significant contribution in increasing trust in Tokopedia users.

The results of this study are in accordance with the results of previous studies, namely according to Park et al. (2011) Hence, if users accept recommendations posted by other consumers as credible, they will be more confident in adopting these suggestions and build positive trust in the seller. Syafaruddin, et al. (2016) the information conveyed by consumers to other consumers is more directed to positive information and in accordance with consumer expectations after they make a purchase about the information provided has a positive influence on consumer confidence. There is a positive and significant effect of eWOM on product trust (Anggitasari and Wijaya, 2016). Dewi (2019) eWOM has a positive and significant effect on trust. Zalni and Abror (2019) eWOM has a positive and significant effect on trust.

The effect of shopping experience on customer loyalty. Based on the data presented in Table 2, it is known that shopping experience has a positive and significant effect on customer loyalty to Tokopedia users in Denpasar. This result means that the better the shopping experience, the higher the customer loyalty for Tokopedia users in Denpasar City.

These results indicate that the values contained in the shopping experience have a significant impact on Tokopedia's customer loyalty. The shopping experience variable measured based on: the experience of obtaining information, pleasant experience, ease of transaction processing, convenience in using the application is considered important proven to be able to affect customer loyalty at Tokopedia. So that it can be interpreted that it will be able to make a significant contribution in increasing customer loyalty to Tokopedia users.

The results of this study are in accordance with the results of previous studies, namely the good experience felt by customers encourages changes in customer behavior patterns, one type of change in behavior patterns is customers who become increasingly loyal (Wardaya and Prasetya, 2017). Macgillavry and Allan Wilson (2014) create a positive customer experience that allows companies to differentiate themselves from the competition, thus greatly influencing the growth of customer loyalty. There is an influence of customer experience on customer loyalty (Anisa et al, 2020). Customer experience has a positive and significant effect on customer loyalty (Dirbawanto et al, 2016).

Effect of shopping experience on trust. Based on the data presented in Table 2, it is known that shopping experience has a positive and significant effect on trust for Tokopedia users in Denpasar. This result means that the better the shopping experience, the higher the trust for Tokopedia users in Denpasar City. 
These results indicate that the values contained in the shopping experience have a significant impact on Tokopedia's trust. The shopping experience variable which is measured based on: the experience of obtaining information, pleasant experience, ease of transaction processing, convenience in using the application is considered important proven to be able to influence trust in Tokopedia. So that it can be interpreted that this will be able to make a significant contribution in increasing trust in Tokopedia users.

The results of this study are in accordance with the results of previous studies, namely according to Xiao et al., (2016) in their research that the online shopping experience has an effect on consumer trust. According to Papas et al., (2014) in their research suggests that trust is important for every consumer, whether they are new consumers or old consumers. Consumer trust must be maintained through their online shopping experience. that experience has a positive and significant effect on trust in consumers (Wibowo, 2016). According to Mohmed et al. (2013) which shows that experience has a positive and significant effect on trust. According to Regina (2018) Prior online purchase experience has a significant influence on online trust.

The effect of trust on customer loyalty. Based on the data presented in Table 2, it is known that trust has a positive and significant effect on customer loyalty to Tokopedia users in Denpasar. This result means that the better the trust, the higher the customer loyalty to Tokopedia users in Denpasar City.

These results indicate that the values contained in the trust have a significant impact on Tokopedia's customer loyalty. The trust variable that is measured is based on: trust in a good reputation, trust in work reliability, trust in security, trust in honesty, trust in using products that are considered important and proven to be able to affect customer loyalty at Tokopedia. So that it can be interpreted that it will be able to make a significant contribution in increasing customer loyalty to Tokopedia users.

The results of this study are in accordance with the results of previous studies, namely according to Mihaela (2013), indicating that there is a strong and significant correlation between customer trust and customer loyalty. A study by Chou (2014) shows that there is a directly proportional relationship between the effect of service quality and customer trust on customer loyalty. There is a direct correlation between customer trust which directs credit customers towards customer loyalty (Nguyen et al., 2013). Customer trust will have a significant and positive effect on changes in customer behavior which tend to be more loyal (Madjid, 2013). The relationship pattern between customer trust and customer loyalty is directly proportional (Wardaya and Prasetya, 2017).

The role of trust in mediating the effect of eWOM on customer loyalty. Based on the data presented in Table 2, it is known that there is an indirect effect of eWOM on customer loyalty through trust in Tokopedia users in Denpasar. The initial result of the coefficient value of the direct influence of eWOM on customer loyalty is 0.303 . The addition of the trust variable as a mediating variable has a different effect on the total effect of eWOM with customer loyalty. The VAF value is 0.375 indicating the mediation value is 37.5 percent, meaning that the variable is classified as a partial mediation variable. In addition, the value of the PLS trust test results on customer loyalty has the highest correlation coefficient of 0.346 . In conclusion, the results in this study indicate that customer loyalty can be increased by eWOM, besides that customer loyalty will increase again if eWOM is able to increase trust.

The results of this study are in accordance with the results of previous studies, namely according to Anggitasari and Wijaya (2016), there is a positive and significant effect of eWOM on product repurchase intention, customer trust in a product. eWOM has a significant impact on purchasing decisions if it is mediated by trust in the product (Dewi, 2019). According to Prasad et al.(2017) stated that trust has an important role as a mediator between eWOM and repeat intentions as a form of customer loyalty. According to Permadi (2019), consumer trust has a full role in mediating the relationship between eWOM and consumer repurchase interest.

The role of trust in mediating the effect of shopping experience on customer loyalty. Based on the data presented in Table 2, it is known that there is an indirect effect of shopping experience on customer loyalty through trust in Tokopedia users in Denpasar. The 
initial result of the coefficient value of the direct influence of shopping experience on customer loyalty is 0.293 . The addition of the trust variable as a mediating variable has a different effect on the effect of total shopping experience with customer loyalty. The VAF value is 0.221 indicating a mediation value of 22.1 percent, meaning that the variable is classified as a partial mediation variable. In addition, the value of the PLS trust test results on customer loyalty has the highest correlation coefficient of 0.346 . In conclusion, the results in this study indicate that customer loyalty can be increased by shopping experience, besides that customer loyalty will increase again if shopping experience is able to increase trust.

The results of this study are in accordance with the results of previous studies, namely according to Putri (2012) the trust and satisfaction of the customer's shopping experience also has a significant effect on repurchase intentions. Trust is also able to mediate between customer satisfactions and repurchase intention. Trust is able to mediate the effect of experience on the intention to reuse a product. It can be concluded that trust partially mediates the effect of experience on intention to reuse, in other words, trust can strengthen experience of intention to reuse a product (Prabandari, 2018). Suandana et al. (2016) stated that trust as a perfect mediator in online purchase experience and intention. Loureiro et al. (2018) explains that trust is able to mediate the effect of consumer satisfaction obtained from customer experience on purchases. Astarin et al. (2017) trust significantly mediates the effect of experience on re-use intention, which means that the experience felt by consumers will have an impact on consumer trust so that it raises re-use intention.

\section{LIMITATIONS}

The scope of the research is only limited to Tokopedia users in Denpasar City, thus research results may have differences regarding the perception or interpretation of each Tokopedia respondent in other cities. This study is only limited to examining the variables of eWOM, shopping experience, trust, and customer loyalty and thus cannot examine in depth the factors outside these variables. This study uses a cross-sectional time design or at a certain point in time, but on the other hand this study observes the dynamics of conditions that change each period, therefore this research is important to be re-examined in the future.

\section{CONCLUSION}

Based on data analysis and previous discussion, the conclusions of this study are as follows: eWOM has a positive and significant effect on customer loyalty to Tokopedia users in Denpasar. This means, the higher the eWOM, the higher the customer loyalty for Tokopedia users in Denpasar. eWOM has a positive and significant effect on trust in Tokopedia users in Denpasar. This means, the higher the eWOM, the higher the trust for Tokopedia users in Denpasar. Shopping experience has a positive and significant effect on customer loyalty to Tokopedia users in Denpasar. This means, the higher the shopping experience, the higher customer loyalty for Tokopedia users in Denpasar. Shopping experience has a positive and significant effect on trust for Tokopedia users in Denpasar. This means, the higher the shopping experience, the higher the trust for Tokopedia users in Denpasar. Trust has a positive and significant effect on customer loyalty to Tokopedia users in Denpasar. This means, the higher the trust, the higher the customer loyalty for Tokopedia users in Denpasar. Trust is able to mediate the effect of eWOM on customer loyalty. This shows that the customer loyalty of Tokopedia users can be increased by eWOM, besides that customer loyalty will increase again if eWOM is able to increase trust. Trust is able to mediate the effect of shopping experience on customer loyalty. The results in this study indicate that the customer loyalty of Tokopedia users can be increased by shopping experience, besides that customer loyalty will increase again if the shopping experience is able to increase trust.

The suggestion that can be given is to be able to increase eWOM of Tokopedia users, it is recommended for Tokopedia management to pay attention to the means of interaction with other consumers because the lowest value results in the average frequency distribution 
of 3.55 for the indicator of the frequency of interaction with other consumers. The means of interaction can be in the form of newsgroups, chatrooms, online community rooms, and others. To be able to increase the customer loyalty of Tokopedia users, it is recommended for Tokopedia management to increase user trust by always protecting users' personal data and socializing that Tokopedia does not use users' personal data for other things, such as trading it with other parties for certain interests so that user trust can be maintained. In addition, Tokopedia needs to be consistent in marketing and updating user friendly features from Tokopedia to maintain the experience of obtaining information, a pleasant experience, ease of transaction processing, and the convenience of using an already good application. To be able to increase the trust of Tokopedia users, it is recommended for Tokopedia management to strengthen its system so that users increasingly believe that Tokopedia account data is safe from burglary. In addition to strengthening the system, the management of Tokopedia should also consider more in making the system so that it is adapted to infrastructure in Indonesia and is more users friendly.

\section{REFERENCES}

1. Adeliasari, Ivana, V., \& Thio, S. 2012. Electronic Word-of-Mouth (eWOM) and Pengaruhnya Terhadap Keputusan Pembelian di Restoran and Kafe Surabaya. Jurnal Bisnis Manajemen, 2010, 218-230.

2. Anggitasari, A. M., \& Wijaya, T. 2016. Pengaruh EWOM Terhadap Brand Image and Brand Trust, Serta Dampaknya Pada Minat Beli Produk Smartphone Iphone (Studi Pada Masyarakat Di Yogyakarta). Jurnal Manajemen Bisnis Indonesia, 5(3), 266- 275.

3. Angkat, D.W., \& Apriatni, E. P. 2018. Pengaruh Kemudahan, Kualitas Informasi, and Kepercayaan Terhadap Keputusan Pembelian Secara Online Pada Situs Lazada. Jurnal Ilmu Administrasi Bisnis Vol 7, No 3.

4. Anisa, A. R., \& Oktini, D. R. 2020. Pengaruh Customer Experience terhadap Customer Loyalty pada Warunk Upnormal Cabang Buah Batu Bandung. Prosiding Manajemen Unisba, Vol 6 No 1, 392-395.

5. Ardyanto, A. S. 2013. Faktor-Faktor Yang Mempengaruhi Brand Trust and Brand FaktorFaktor yang Mempengaruhi Brand Trust and Brand Commitment Pada Situs Buka Lapak.com di Surabaya. Jurnal IImiah Mahasiswa Manajemen, Vol.2 No.1, pp.2-5.

6. Astarina, I. G. A., Giantari, I. G. A. K., \& Yasa, N. N. K. 2017. Peran Kepercayaan Memediasi Pengaruh Pengalaman terhadap Niat Menggunakan Kembali Jasa Gojek di Kota Denpasar. E-Jurnal Manajemen Universitas Udayana, 6(5), 2308- 2334.

7. Atika, A., Kusumawati, A., \& lqbal, M. 2017. the Effect of Electronic Word of Mouth, Message Source Credibility, Information Quality on Brand Image and Purchase intention. $\begin{array}{llll}\text { Jurnal Ekonomi } & \text { and }\end{array}$ https://doi.org/10.24034/j25485024.y2016.v20.i1.1780

8. Bu, Q., Jin, Y., \& Li, Z. 2020. How does a customer prefer community or brand? The impacts of customer experience on customer loyalty based on the perspective of value co-creation. Journal of Contemporary Marketing Science, 3(3), 281-302. https://doi.org/10.1108/jcmars-02-2020-0009

9. Chou, P. F. 2014. An Evaluation of Service Quality, Trust, And Customer Loyalty In Home-Delivery Services. International Journal of Research In Social Sciences, 3(8).

10. Dewi, N. S. 2019. Peran Kepercayaan Merek Memediasi Electronic Word of Mouth Terhadap Keputusan Pembelian. E-Jurnal Manajemen Universitas Udayana, 8(6), 3784. https://doi.org/10.24843/ejmunud.2019.v08.i06.p18

11. Dirbawanto, N. D., \& Sutrasmawati, E. ng. 2016. Pengaruh Customer Experience and Brand Trust Terhadap Customer Loyalty. Management Analysis Journal, 5(1), 70-76.

12. Giantari, I. G. A. K., Zain, D., Rahayu, M., \& Solimun. 2013. The Role of Perceived Behavioral Control and Trust as Mediator of Experience on Online Purchasing Intentions Relationship a Study on Youths in Denpasar City (Indonesia). International Journal of Business and Management Invention, 2(1), 30-38.

13. Goyette, I., Ricard,L.,Bergeron, J. \& Marticotte, F. 2010. eWOM Scale: Word-of-Mouth 
Measurement Scale for e-Services Context, Canadian Journal of Administrative Sciences, 27(1), 5-23.

14. Jacobsen, S. 2018. Why did I buy this?: The effect of WOM and online reviews on post purchase attribution for product outcomes. Journal of Research in Interactive Marketing, 12(3), 370-395. https://doi.org/10.1108/JRIM-12-2017-0102

15. Kadek, W. S. N. 2015. Pengaruh E-Wom Terhadap Citra Rumah Sakit, Kepuasan and Loyalitas Pada Rumah Sakit Bali Royal Hospital I. Umy Repository, 1(1), 1-11.

16. Kala, D., \& Chaubey, D. S. 2018. The effect of eWOM communication on brand image and purchase intention towards lifestyle products in India. International Journal of Services, Economics and Management, 9(2), 143-157.

17. Karjaluoto, H., Munnukka, J., \& Kiuru, K. 2016. Brand Love and Positive Word of Mouth: The Moderating Effects of Experience and Price. Journal of Product and Brand Management, 25(6), 527-537. https://doi.org/10.1108/JPBM-03-2015-

18. Kim, S. \& Park, H. 2013. "Effects of various characteristics of s-commerce on consumers' trust and trust performance", International Journal of Information Management, Vol. 33 No. 2, pp. 318-332.

19. King, R.A., Racherla, P. \& Bush, V.D. 2014. “What we know and don't know about online word-ofmouth: a review and synthesis of the literature", Journal of Interactive Marketing, Vol. 28 No. 3, pp. 167-183.

20. Liu, Y., \& Tang, X. 2018. The effects of online trust-building mechanisms on trust and repurchase intentions: An empirical study on eBay. Information Technology and People, 31(3), 666-687. https://doi.org/10.1108/ITP-10-2016-0242

21. Macgillavry, \& Wilson, A. 2014. Delivering Loyalty Via Customer Experience Management at DHL Freight, Journal Business and Organizational Exellence, Vol. 33, Issue 6.

22. Madjid, R. 2013. Customer Trust as Relationship Mediation Between Customer Satisfaction and Loyalty At Bank Rakyat Indonesia (BRI) Southeast Sulawesi. The International Journal Of Engineering And Science (JJES), 2(5), 48-60.

23. Megantara, I. M. T., \& Suryani, A. 2016. Penentu Niat Pembelian Kembali Tiket Pesawat secara Online pada Situs Traveloka.com. E-Jurnal Manajemen Universitas Udayana, $5(8), 1-28$.

24. Mihaela, S. T. 2013. The Influence of Overall Satisfaction and Trust On Customer Loyalty. Management \& Marketing Challenges for the Knowledge Society, 8(1), 109- 128.

25. Mohmed, A.S., Imhmed, N.B.A., \& Zalisham M.J. 2013. The Impact of Trust and Past Experience on Intention to Purchase in E-Commerce. International Journal of Engineering Research and Development, Vol. 7 (10), 28-35.

26. Nguyen, N., Leclerc, A., \& LeBlanc, G. 2013. The Mediating Role of Customer Trust on Customer Loyalty. Journal of Service Science and Management, 6, 96-109.

27. Papas, Ilias O. Adamantia G. Pateli, Michail N. G., \& Vassilios C. 2014. Moderating Effects of Online Shopping Experience on Customer Satisfaction and Repurchase intentions. International Journal of Retail \& Distribution Management Vol. 42 No. 3, pp. 187-204

28. Parastanti, G. 2014. Pengaruh Prior Online Purchase Experience Terhadap Trust and Online Repurchase intention (Survey Pada Pelanggan Zalora Indonesia Melalui Website Www.Zalora.Co.Id). Jurnal Administrasi Bisnis S1 Universitas Brawijaya, 16(1), 84979.

29. Parastanti, G. P., Kumadji, S., \& Hidayat, K. 2014. Pengaruh Prior Online Purchase Experience terhadap Trust and Online Repurchase intention (Survey pada Pelanggan Zalora Indonesia Melalui Website www.zalora.co.id). Jurnal Administrasi Bisnis (JAB), 16(1).

30. Park, Ch., Wang, Y., Yao, Y. \& Kang, Y.R. 2011. "Factors influencing eWOM effects: using experience, credibility and susceptibility", International Journal of Social Science and Humanity, Vol. 1 No. 1, pp. 74-79

31. Patel, N. 2014. "How to make more money without making more sales", diunduh dari forbes.com, website: www.forbes.com/sites/neilpatel/2014/11/17/how-to-make- moremoney-without-making-more-sales/\#742a69fe23aa 
32. Permadi, F. 2019. Pengaruh Electronic Word Of Mouth Terhadap Minat Beli Yang Dimediasi Oleh Kepercayaan (Studi Pada Pengunjung Situs Tokopedia.com). Jurnal Ilmiah Mahasiswa Fakultas Ekonomi and Bisnis Universitas Brawijaya, 1-18.

33. Prabandari, K. D. 2018. Peran Kepercayaan Memediasi Pengaruh Pengalaman Terhadap Niat Menggunakan Kembali Jasa Jne Di Kota Denpasar. E-Jurnal Manajemen Universitas Udayana, 8(2),700.

34. Prasad, S., Gupta, I. C. \& Totala, N. K.2017. Social Media Usage, Electronic Word of Mouth and Purchase Decision Involvement.Asia-Pacific Journal of Business Administration. 9(2), pp: 1-30.

35. Prastyaningsih, A. 2014. Pengaruh Customer Experience Terhadap Repurchase intention (Niat Membeli Ulang) (Survei Pada Konsumen Kfc Di Lingkungan Warga Rw 3 Desa Kandangrejo, Kedungpring, Lamongan). Jurnal Administrasi Bisnis S1 Universitas Brawijaya, 16(1), 84951.

36. Pujiawati, S. 2020. Pengaruh Customer Experience Customer Satisfaction and Brand Image Terhadap Customer Loyalty Pada Armor Kopi. e-Proceeding of Management, 7(2), 3700-3709.

37. Purwanda, E., \& Wati, T. 2018. Pengaruh Electronic Word Of Mouth, Kepercayaan and Kepuasan Terhadap Loyalitas Pelangga(Survey Pada Pelanggan Lazada Di Wilayah Bandung Timur). Jurnal INTEKNA, 18(2), 86-91.

38. Putra, I. K. T. E., Sukaatmadja, I. P. G., \& Yasa, N. N. K. .2016. Dikota Denpasar Berdasar Theory Of Planned Behavior Fakultas Ekonomi and Bisnis Universitas Udayana (Unud), Bali, Indonesia Pendahuluan Maraknya Bisnis Waralaba Restoran Fast Food Di Daerah Denpasar Seperti Kentucky Fried Chicken, Mcdonald, Pizza Hut. E-Jurnal Ekonomi and Bisnis Universitas Udayana, 8, 2609-2638.

39. Putra, AN., Alit .I. W., Wardana, M. \& Sukaatmaja, I. P. G. 2016. Pengaruh E-Servqual Terhadap Customer Satisfaction, Trust, and Word Of Mouth Peserta BPJS Ketenagakerjaan. E-Jurnal Ekonomi and Bisnis Universitas Udayana, Vol 5, No 11

40. Putri, V. P. 2012. Influence Of Trust And Customer Satisfaction On Repurchase intention At Online Shop In The Facebook. Department Of Management Feb Umm, 33-42.

41. Regina, E. S. 2018. Pengaruh Prior Online Purchase Experience and Online Trust Terhadap Online Repurchase Intention Di Online Shop Veresa. Jurnal Teknik Pomuk Petra, 1-6.

42. Saleem, Zahra and Yaseen. 2017. Impact of Service Quality and Trust on Repurchase intentions. Asia Pacific Journal of Marketing and Logistics, 29 (5), 1136-1159.

43. Schiffman, L. G. \& Kanuk, L. L. 2011. Consumer Behaviour, Edisi Kesepuluh.

44. Serra Cantallops, A., Ramon Cardona, J., \& Salvi, F. 2018. The impact of positive emotional experiences on eWOM generation and loyalty. Spanish Journal of Marketing ESIC, 22(2), 142-162. https://doi.org/10.1108/SJME-03-2018-0009

45. Suandana, N. P. W., Rahyuda, K., \& Yasa, N. N. K.. 2016. Pengaruh Pengalaman Membeli Produk Fashion Terhadap Niat Membeli Kembali Melalui Kepuasan and Kepercayaan Pelanggan. Jurnal Manajemen, Strategi Bisnis, and Kewirausahaan, 10 (1), 85-97.

46. Teng, S., Khong, K.W., Goh, W.W. and Chong, A.Y.L. 2014. "Examining the antecedents of persuasive EWOM messages in social media", Online Information Review, Vol. 38 No. 6, pp. 746-768.

47. Tingting, A. B. J. A. K. 2014. Towards a Unified Customer Experience in Online Shopping Environments: Antecedents and Outcomes. International Journal of Quality and Service Sciences, 8(1).

48. Trenz, M. \& Berger, B. 2013. "Analyzing online customer Reviews-An interdisciplinary literature review and research agenda". ECIS p. 83.

49. Trivedi, S. K., \& Yadav, M. 2017. Predicting online repurchase intentions with eSatisfaction as mediator: a study on Gen Y. Vine. Journal of Information and Knowledge Management Systems, 48(3), 427-447

50. UPS. 2016. "2016 UPS pulse of the online shopper", available at: https://pressroom.ups.com/assets/pdf/2016_UPS_Pulse\%20of\%20the\%20Online 
51. Wardaya, E. P. 2017. Pengaruh Customer Experience terhadap Customer Loyalty melalui Customer Satisfaction and Customer Trust pada Pelanggan Bengkel Auto 2000 di Surabaya Eka. Petra Business \& Management Review, 3(1), 27-45.

52. Wibowo, B. A. 2016. Analisis Pengaruh Faktor Sosial and Pengalaman Terhadap Kepercayaan Untuk Meningkatkan Keputusan Pembelian Customer to Customer (C2C) E - Commerce di Semarang. Diponegoro Journal of Management, vol. 5, no. 3,

53. Widjaja, A. T. 2016. Pengaruh Word of Mouth and Electronic Word of Mouth. Jurnal Bisnis and Manajemen, 53, 241-253.

54. Wilson, N., \& Keni, K. 2018. Pengaruh Website Design Quality and Kualitas Jasa Terhadap Repurchase intention: Variabel Trust Sebagai Variabel Mediasi. Jurnal Manajemen and Pemasaran Jasa, 11(2), 291.

55. Wirtz, J., Chew, P., Lovelock, C. 2012. Essentials of Service Marketing $2^{\text {nd }}$ edition. Singapore: Pearson Education South East Asia.

56. Xiao, Lin, Zixiu Guo, John D'Ambra, and Bin Fu. 2016. Building Loyalty In E- Commerce Towards A Multidimensional Trust-Based Framework For The Case Of China. Program Electronic Library and Information Systems, 50(4):431-461.

57. Yacouel, N. and Fleischer, A. 2012. "The role of cybermediaries in reputation building and price premiums in the online hotel market", Journal of Travel Research, Vol. 51 No. 2, pp. 219-226.

58. Yang, S., Song, Y., Chen, S. and Xia, X. 2017. "Why are customers loyal in sharingeconomy services? A relational benefits perspective", Journal of Services Marketing, Vol. 31 No. 1 , pp. 48-62.

59. Zalni, Z. R., \& Abror. 2019. Pengaruh Reputasi, Electronic Word of Mouth and Web Quality Terhadap Kepercayaan Pelanggan Shopee di Kota Padang. Jurnal Kajian Manajemen and Wirausaha, 01(2), 97-107.

60. Zhang, Y., Fang, Y., Wei, K.-K., Ramsey, E., Mccole, P. and Chen, H. 2011. "Repurchase intention in B2C e-commerce - a relationship quality perspective", Information \& Management, Vol. 48 No. 6, pp. 192-200.

61. Zhong, Y. and Moon, H. 2020. "What drives customer satisfaction, loyalty, and happiness in fast-food restaurants in China? Perceived price, service quality, food quality, physical environment quality, and the moderating role of gender", Food Journal, Vol. 19 No. 1, pp. 1-19. 